REVIEWS

UDC $576.38+575.16$

\title{
Stem cells and genetic diseases
}

\author{
S. Shahid, S. Irshad
}

Institute of Biochemistry and Biotechnology, University of the Punjab

Lahore, Pakistan

saba.ibb@pu.edu.pk

\begin{abstract}
In this review, we have discussed a role of stem cells in the treatment of genetic diseases including cochlear and retinal regeneration. The most perceptive use of stem cells at the genetic diseases is cellular repair of tissues affected by a genetic mutation when stem cells without such mutation are transplanted to restore normal tissue function.
\end{abstract}

Keywords: stem cell, genetic disease, cochlea, retina, regeneration

Introduction. Stem cells are characterized as undifferentiated [1,2], toti-, multi- or pluripotent [3], and selfrenewing cells [4] that have the capability to differentiate into any cell type of the body given suitable intracellular gene regulation [5], intercellular communication [6] and environmental clues. These cells hold the promise of ultimate replacement of the lost cells and possibly organs [7]. There are three types of stem cells: (1) embryonic stem cells, (2) adult stem cells, (3) induced pluripotent stem cells (iPSCs); each with its own potential and limitations [8]. Stem cell therapy is based on the concept that the undifferentiated stem cell has the potential to respond and react to surrounding cell signals and differentiate into the appropriate cell type associated with the signal [9] to restore normal tissue function after transplantation [10].

Potential of stem cells to cure genetic diseases. Pluripotent stem cells possess a unique property of differentiating into all other cell types of the human body [11]. Human embryonic stem cells (HESCs) carrying specific mutations provide an important tool for investigating genetic diseases in humans [12]. HESCs can be used for better understanding the fundamental developmental processes and can, therefore, serve for studying genetic disorders for which no good research model

(C) Institute of Molecular Biology and Genetics, NAS of Ukraine, 2012 exists. Preimplantation genetic diagnosis of in vitro derived embryos results in affected-spare blastocysts with specific known inherited mutations. These affected blastocysts can be used for the derivation of diseasebearing HESCs, which would serve for studying the molecular and pathophysiological mechanisms underlying the genetic disease for which they were diagnosed [13]. The field of stem-cell biology has been projected forward by the startling development of reprogramming technology. The capability to restore pluripotency to somatic cells through the ectopic co-expression of reprogramming factors has established powerful new prospects for modeling human diseases and offers hope for specified regenerative cell therapies [14]. The reprogramming of human somatic cells make use of easily accessible tissue, such as blood or skin, to produce embryonic-like induced pluripotent stem cells [15]. This procedure utilizes retroviruses/adenovirus/ lentiviruses/plasmids to incorporate candidate genes into somatic cells isolated from any part of the human body [11]. In 2007, germline transmission was achieved with mouse iPSCs [16-18], and iPSCs were generated from human fibroblasts [19-21]. Then iPSCs were generated from patients with thalassemia [22] and a variety of genetic diseases with either Mendelian or complex inheritance [23]. It is also possible to develop disease-specific iPSCs which are most likely to revolu- 
tionize research regarding the pathophysiology of most devastating diseases [11].

Methods for genetic repair. There are several methods for genetic repair of genetic diseases that include zinc finger [24] and transcription activator-like effector (TALE) nuclease method [25], exon skipping technology [26], RNA interference (RNAi) [27] and gene transfer method [28]. However, already damaged cells should be replaced by new normal cells which can be differentiated from iPSCs. Those methods may be used to repair the genetic disease-harboring cells that may be done either in the somatic cells before induction to pluripotency [29], or the somatic cell derived iPSCs [30]. In genetic diseases, where the cells are already damaged, they can be replaced by new normal cells, which can be differentiated from iPSCs. To avoid immune rejection, iPSCs from the patient's own cell can be developed. However, iPSCs from the patient's own cell harbors the same genetic aberration. Therefore, genetic repair should be done before differentiating the iPSCs into required cells [31].

Role of stem cells for regenerating cochlear hair cells. Hearing loss, caused by irreversible loss of cochlear sensory hair cells [32], affects millions of patients worldwide [33]. Approximately $50 \%$ of the elderly people suffer from some degree of hearing loss influencing their social interactions [7]. In contrast to many non-mammalian vertebrates [34], humans and other mammals cannot regenerate hair cells. Therefore, cochlear transplants represented a technological breakthrough [35], however they cannot match the innate capability of the fully functional organ of Corti to distinguish sound as a continuum of frequencies. The current development of cellular and molecular therapy with multipotent or pluripotent stem cells puts forward the new solutions for hearing loss to attain natural hearing by restoring the lost hair cells $[36,37]$. Stem cells are beneficial for exploring the molecular pathways that trigger cochlear regeneration [38]. Past research has detected several sources of stem cells in human ears. For example, apparent neuronal precursors have been identified from human biopsies of spiral ganglion explants [39]. Other sources of apparent stem cells such as the organ of Corti, stria vascularis [40] and the vestibular organs, even from postmortem specimens have also been identified [41]. Stem cells originated from several sources such as bone marrow [42], different neural tissues [43], or neurosensory precursors [44] have been examined for their capability to develop into hair-celllike cells and to survive when injected into the ear, producing an extensive literature demonstrating how best to implant cells for neuronal replacement $[36,45,46]$, or sensory implants [47].

Embryonic stem cells for regenerating cochlear hair cells. Embryonic Stem Cells (ESCs) are pluripotent and capable of giving rise to cells from any of the three germ layers. The ESCs were differentiated toward the ectodermal lineage and the generated progenitor cells had the capability to develop into sensory hair cells in vitro $[48,49]$. ESCs are isolated from the inner cell mass of early embryos that possess three general properties that make them suitable for cell replacement therapy. [43]. ESCs have been reported to produce sensory auditory neurons and neural progenitors with the potential to restore auditory function by generating nerve connections to hair cells $[45,50]$. ESCs come from the inner cell mass of the pre-implanted blastocyst and can be differentiated into virtually any cell type as they are totipotent and have the ability to regenerate or selfrenewal that can be attributed to the expression of specific genes such as OCT4, SOX2, and NANOG [51]. Deregulation of any or all these genes causes ESCs to lose differentiation and pluripotency. Notably, ESCs are subjected to immune responses that might eventually result in the rejection of derivative cells by the host. Even though immunosuppressive therapy can counteract ESCs rejection, it also causes the decreased ability to fight against opportunistic infections and other sideeffects such as diabetes, osteoporosis, hypertension and kidney failure [52]. ESCs have high migration rates and survival capacity when implanted into the cochlea [53]. They migrated onto auditory neurons and showed neuronal differentiation [54]. Although they can be differentiated into a number of cell lineages, they tend to differentiate more toward the mesoderm and can be used to replace degenerated cochlear fibrocytes [55]. However, ESCs revealed low integration into endogenous tissue and failed to differentiate completely at the implantation site [54]. There is also the risk of tumor formation and the risk of transmitting infections with ESCs because they use animal products during the culturing process. ESCs used in the treatment of inner ear 
can make use of cloning to prevent graft- $v s$-host diseases $[56,57]$.

Adult stem cells for regenerating cochlear hair cells. An alternative to ESCs are Adult Stem (AS) cells which are pluripotent [58]. AS cells have been detected in several organs including the ear [37] and can differentiate into a variety of other cell types. However, it is difficult to retrieve the ear stem cells without destroying normal function of the organ, so they are not suitable candidate for human therapies. Furthermore, isogenic AS cells have the potential to escape immune rejection because they are isolated from the same individual that will later receive derivative cells for therapy [7]. AS cells from many tissues are now being used to find cures for numerous diseases. These cells are not related to any ethical issues and can move into clinical trials involving autologous transplantation therapies. Bone marrowderived stem cells have shown the most promising results to cure inner ear disorders [59]. Replacement therapies with bone marrow-derived hematopoietic stem cells (BMHSCs) in mice suggested the possibility to differentiate into fibrocytes and mesenchymal cells in the adult inner ear. BMHSCs showed their potential to reduce cochlear injury by replacing fibrocytes and mesenchymal cells in the inner ear [60]. Furthermore, the differentiated cells displayed the morphological characteristics of hair cell stereociliary bundles. The investigations have shown that bone marrow mesenchymal stem cells, stimulated in the presence of growth factors, were capable to form neuronal progenitor cells, and after being transfected with the Math1 gene, were able to differentiate into the inner ear sensory-like cells [42]. Bone marrow mesenchymal stem cells have the potential to differentiate into the auditory neurons both in vivo and in vitro [56], establishing that a wide variety of inner ear cell types can be generated from stem cells. AS cells isolated from the macular organs of mouse have been shown to differentiate into the hair cell-like cells in the presence of extrinsic factors [61]. AS cells also have the potential to deliver gene and therapeutic molecules to other parts of the inner ear. For example, a protein present in cochlear gap junctions and supporting cells, Connexin 26, was expressed when bone marrow stromal cells were transplanted into the perilymphatic space of the mouse cochlea [62]. AS cells isolated from olfactory neuroepithelium expressed hair cell markers and bear a phenotypic resemblance to hair cells when cocultured with cochlear cell [61]. These studies suggest that AS cells provide a significant potential treatment for hearing loss.

Induced pluripotent stem cells for regenerating cochlear hair cells. The discovery of iPSCs established a new dimension to stem cell research. iPSCs are produced from fibroblasts [18], AS cells and other somatic cells, which are reprogrammed to express specific genes and retain the characteristic properties of ESCs [63]. A two-step approach has been proposed using a first set of transcription factors to increase the generation of iPSCs and a second set of factors to initiate the hair cell differentiation [7]. It has been demonstrated that human neural stem cells can be directly reprogrammed to iPSCs by just expressing Oct4 [64]. Mostly, the research with iPSCs in hair cell regeneration is of murine origin. A recent study has shown the generation of iPSCs from murine embryonic fibroblasts which were transduced with retroviruses to express $O c t 4, c-M y c$, Sox 2 and Klf4. The iPSCs generated were cultured to produce otic progenitors. The generated otic progenitor cells differentiated into hair cell-like cells expressing hair cell markers. The differentiated cells, when co-cultured with fibroblast-like cells from embryonic chicken utricles, produced hair bundle-like projections, revealed transduction currents and showed response to mechanical stimulation [48].

The use of iPSCs to restore auditory neuronal ganglions was investigated. In vitro neuronal differentiation of iPSCs was induced by exposing them to stromal cellderived inducing activity (SDIA). SDIA is a neural inducing activity established in stromal cells when they produce inhibitory and inducing factors, simultaneously. The differentiated cells were then transplanted into the cochlea of mice. iPSCs cell-derived neurons projecting toward the cochlear hair cells were observed after transplantation [65]. iPSCs provided the opportunity of generating and using patient-specific stem cells in vivo without immune rejection and there are no controversial ethical issues associated with their usage as with human ESCs [7]. Their undifferentiated state permits them to migrate to regions surrounding the cochlea. However, one of the key concerns with iPSCs is the time required to generate the individual cell lines [66]. 
Role of stem cells in retinal regeneration. Retinal diseases are among the leading causes of irreversible visual impairment and blindness [67], affecting over a hundred million individuals worldwide. The retina consists of complex neural circuit that transduces the light into the electrical signals which are then sent through the optic nerve to the higher centers in the brain for further processing, necessary for perception. Retinal diseases are characterized by progressive degeneration of retina due to malfunctioning of one or more types of the cells involved in visual function, ultimately resulting in loss of vision [68]. In the last decade, there has been a dramatic increase in the number of genes implicated in inherited retinal disease [69]. Among the retinal degenerative diseases, the age-related macular degeneration (AMD) is the leading cause of permanent blindness in the elderly, especially in developed countries. The inherited retinal degeneration is a main reason for visual impairment in the juvenile-to-young adult population. Particularly, the retinitis pigmentosa (RP) is a leading cause of visual impairment or inherited blindness. Related diseases, including a genetic condition called Stargardt's macular dystrophy, affect young people, as well in which fatty deposits build up behind the retina, causing its degeneration and resulting in vision loss [8]. The retina is an excellent model to examine stem cell transplantation into the central nervous system (CNS). The retina develops from the same embryonic origin as the brain, but it is more easily accessible than other parts of the CNS [68]. Scientists are struggling for establishing a challenging treatment for both macular degeneration and macular dystrophy. They are injecting replacement cells into the back of the eye for restoration of the retina. The company running the trials, Advanced Cell Technology, makes the replacement eye cells from HESCs [8]. It is clear that several stem cells retain inherent neuroprotective properties when transplanted into the injured CNS. Stem cells, particularly the somatic neural stem cells and mesenchymal stem cells (MSCs), have been reported to provoke neuroprotective properties via the natural secretion of high levels of neurotrophic factors [70] and/or inflammatory modulators [71]. Additionally, stem cell transplantation has been used as a vehicle for selective neurotrophic factor delivery, using a variety of cells including the stem cells genetically modified to hyper secretes neurotrophins [72]. Wi- thin the CNS, neuroprotective stem cell therapies are likely to be translated to clinical treatments more rapidly than neuroreplacement therapies given that they entail only that transplanted cells which survive in vivo and continue to provide support to the host neurons without noteworthy adverse effects [73]. Clinical trials are in the early stages, and data on safety and efficacy are widely predictable. The encouraging results from these stem cell-based clinical studies would radically alter the way that blinding di sorders are come up to the clinics [74]. In 2010, the Food and Drug Administration (FDA) approved a phase I/II clinical trial HESC-derived retinal pigment epithelium (RPE) cells for the treatment of dry AMD. Despite the possibility of curing the degenerative process [75], there are still many obstacles before stem cell technology can be applied in daily practice [76]. The success of stem cell transplantation is largely dependent upon the ability of donor cells migration to the required site, survival after transplantation, and differentiation into retinal cells for restoring retinal function. Studies have shown that several cell populations may be regarded as potential sources for retinal regeneration. These include embryonic stem cells, adult stem cells and induced pluripotent stem cells [76].

Embryonic-stem-cell-derived retinal regeneration. ESCs provide potentially unlimited sources for the generation of retinal cells. In vitro differentiation of ESCs into functional retinal cell types is attainable by defined step-wise protocols [77-80]. ESCs could be induced to differentiate into eye-like structures that comprised cells with crystalline lens properties, neural retina, and RPE. Furthermore, it has been found that cells from these eyelike structures could be further differentiated into retinal ganglion cells (RGCs) when transplanted into the vitreous of an injured adult mouse retina [81]. The success of defined differentiation of HESC-derived RPE cells (HESC-RPE) has been reported [82]. Following transplantation in animal models, vision restoration has been reported and no tumor formation was observed [80]. Transplantation of photoreceptors with or without RPE cells derived from these sources provides huge potential for treating retinal degenerations [76]. Eiraku et al. [83] reported the dynamic, autonomous development of the retinal primordium (optic cup) from a three-dimensional culture of mouse ESC aggregates. Aftab et al. have described that donor tissues taken from $16^{\text {th }}$ to 
$18^{\text {th }}$ week of gestation period show the longest in-vitro survival time, and the highest number of cells. After replacement, these cells were integrated into the retina of the recipient, and differentiated into rhodopsin positive cells, hence, favored the potential of human retinal progenitor cell transplantation for degenerative diseases [84]. Lamba et al. demonstrated that the human embryonic stem cell-derived photoreceptors could integrate and enhance visual function when transplanted into adult blind mice, revealing the capability of using in vitro-derived human photoreceptors for vision restoration [85]. The putative RPE cells derived from HESCs displayed morphological characteristics of the human RPE cells and expressed molecular markers. The transplanted RPE cells derived from HESCs in the defined culture condition successfully survived and migrated within subretinal space of rat retinal degeneration model, thus support the feasibility of the HESCs derived RPE cells for cell-based retinal regenerative therapy [86]. Nevertheless, controversial issues still exist, ethical concerns and immune rejection risk have restricted the HESCbased therapy in clinics and the supply of such cells is limited [84].

Adult stem cells derived retinal regeneration. Retinal stem cells (RSCs) are present in the ciliary margin of the adult human eye and can give rise to all retinal cell types [87]. In 2006, it was reported that the degenerating retina was receptive to new cellular input and postmitotic photoreceptors, rather than immature progenitor cells [88]. It was shown that a single pigmented ciliary epithelium $(\mathrm{CE})$ cell of mouse retina could proliferate clonally in vitro and form sphere colonies. These cells have the capability to be induced into retinal-specific cell types, including Muller glial cells, bipolar neurons and rod photoreceptors [89]. Later, similar multipotent retinal stem cells were identified in other mammals-like pigs and humans [90]. Moreover, it was found that the expansion of CE-derived cells rapidly led to the loss of retinal progenitor cell markers and consequently reduced the potential of photoreceptor differentiation [91]. AS cells, that have been reported to be capable of inducing retinal regeneration, include hematopoietic stem cells (hSCs), neural progenitor cells (NPCs) [92] and MSCs [93]. Neural progenitors have been demonstrated to promote the recovery from retinal injury and to express retinal phenotypic neurochemical markers.
However, it has been shown that NPCs have scarce ability to differentiate into mature retinal neurons. Also, further applications of NPCs are limited due to the shortage of adult NPCs sources. Autologous transplantation using MSCs or hSCs has the advantage of reducing the rejection risk and avoiding ethical issues. Anatomical integration has been reported by intravitreal injection of hSCs using retinal ischemia-reperfusion models [94] and MSCs. The studies on animals have demonstrated that MSCs are able to integrate into the nerve fiber layers and ganglion cells [95]. The functional retinal differentiation from MSCs or hSCs is still highly debatable. It has been demonstrated that improvements with the use of adult MSCs or hSCs may actually be attributed to the anti-inflammatory cytokines and neurotrophic factors, instead of direct functional retinal differentiation [96]. Adult retina-specific stem cells discovery pursued different research laboratories to expand numbers of such adult retina-specific stem cells and optimize sub-retinal differentiation. However, there are some obstacles to the use of such cells. Firstly, the percentage of actively proliferating cells in the CE is very low $(<2 \%)$. Secondly, self-renewal and proliferation rates would decrease gradually with subsequent passages [97]. Thirdly, there may be a risk of tumor formation [98].

Induced pluripotent stem cells derived retinal regeneration. The absence of a regenerative pathway for damaged retina following injury or disease has led to experiments using stem cell transplantation for retinal regeneration [99]. iPSCs are both an unlimited source for retinal repair and hoping means for genetic disease modeling and pharmaceutical projects, [67] and encouraging results have been demonstrated in rodents [99]. iPSCs can be transplanted and integrated into the retina of adult mice as well-differentiated retinal cells. Thus, these cells have the potential to be exploited to recover and regenerate diseased retina as cell replacement therapy [100]. Induced pluripotent stem cells are ESCslike pluripotent cells able to differentiate into the majority of body cells. This potential ensures an unlimited source of differentiated cells to replace those lost in many human degenerative diseases [67]. Both three-factor $(O c t 3 / 4$, Sox 2 and Klf4) and four-factor (Oct3/4, Sox2, $K l f 4$ and $c-M y c$ ) human iPSCs could be successfully differentiated into retinal cells by small-molecule induc- 
tion [77]. Hara et al. described the in vitro differentiation of retinal cells from HPSCs by small-molecule induction, including ganglion cells, and photoreceptor cells from iPSCs transplanted into mouse retina [100]. The iPSCs of swine eye which is a close anatomical and physiological match to the human eye can differentiate into photoreceptors in culture, and these cells can integrate into the damaged swine neural retina, thus, leaving foundation stone for further research using the pig as a model for retinal stem cell transplantation [99]. The ocular cells such as RPE are of particular interest because they could be used to treat the degenerative eye diseases, including age-related macular degeneration and RP. iPSCs can differentiate into functional RPE that are quantitatively similar to HESC-RPE in their differentiation potential [79]. RPE generated from these human iPSCs revealed a disease-specific functional defect that could be corrected either by pharmacological means or following targeted gene repair [101].

However, the major risk with a possible transplantation of human iPSCs cells under retinal diseases is their ability to form tumors including mature and immature teratoma [100].

\section{C. Шахід, C. Іршад}

Стовбурові клітини і генетичні захворювання

Резюме

Обговорюється роль стовбурових клітин у лікуванні генетичних захворювань, таких як випадіння волосся і регенерація сітківки. При корекиії генетичних захворювань, спричинених наявністю певних мутацій, найперспективнішим вважають пересадження стовбурових клітин без таких мутаиій для подальшой клітинноі регенерації і відновлення нормальних функиій тканин.

Ключові слова: стовбурові клітини, генетичні захворювання, завитка, сітківка ока, регенерація

\section{С. Шахид, С. Ириад}

Стволовые клетки и генетические заболевания

\section{Резюме}

Обсуждается роль стволовых клеток в лечении генетических заболеваний, таких как выпадение волос и регенерация сетчатки. При коррекции генетических заболеваний, вызванных наличием определенных мутаций, наиболее перспективным считают пересадку стволовых клеток без таких мутаций для последующей клеточной регенерации и восстановления нормальных функиий тканей.

Ключевые слова: стволовые клетки, генетические заболевания, улитка, сетчатка глаза, регенерация.

\section{REFERENCES}

1. Kageyama R., Shimojo H., Ohtsuka T., Imayoshi I. Maintenance of neural stem cells in the brain: role of Notch signaling // Stem Cells and Cancer Stem Cells.-2012.-4, Part 1.-P. 31-39.

2. Baumann K. Stem cells: Self-help in the niche // Nat. Rev. Mol. Cell Biol.-2012.-13, N 61. doi:10.1038/nrm3279.

3. Imura T. Adult Neural Stem Cells; Identity and Regulation // Stem Cells and Cancer Stem Cells.-2012.-4, N 1.-P. 77-84.

4. Gilbert P. M., Corbel S., Doyonnas R., Havenstrite K., Magnusson K. E., Blau H. M. A single cell bioengineering approach to elucidate mechanisms of adult stem cell self-renewal // Integr. Biol. (Camb.).-2012.-4, N 4.-P. 360-367.

5. Kaneko K. Characterization of stem cells and cancer cells on the basis of gene expression profile stability, plasticity, and robustness: dynamical systems theory of gene expressions under cellcell interaction explains mutational robustness of differentiated cells and suggests how cancer cells emerge // Bioessays.2011.-33, N 6.-P. 403-413.

6. Wong R. C. B., Pera M. F., Pebay A. Role of gap junctions in embryonic and somatic stem cells // Stem Cell Rev.-2008.-4, N 4.-P. 283-292.

7. Beisel K., Hansen L., Soukup G., Fritzsch B. Regenerating cochlear hair cells: quo vadis stem cell // Cell Tissue Res.-2008.333, N 3.-P. 373-379.

8. Shevde N. Stem cells: flexible friends // Nature.-2012.-483, N 7387, suppl.-S22-S26.

9. Okano T., Kelley M. W. Stem cell therapy for the Inner ear: recent advances and future directions // Trends Ampl.-2012.-16, N 1.-P. 4-18.

10. Mackay-Sim A., Silburn P. Stem cells and genetic disease // Cell Prolif.-2008.-41, Suppl. 1.-P. 85-93.

11. Das K. A., Pal R. Induced pluripotent stem cells (iPSCs): the emergence of a new champion in stem cell technology-driven biomedical applications // J. Tissue Eng. Regen. Med.-2010.-4, N 6.-P. 413-421.

12. Frumkin T., Malcov M., Telias M., Gold V., Schwartz T., Azem F., Amit A., Yaron Y., Ben-Yosef D. Human embryonic stem cells carrying mutations for severe genetic disorders // In Vitro Cell. Dev. Biol. Anim.-2010.-46, N 3-4.-P. 327-336.

13. Ben-Yehudah A., Malcov M., Frumkin T., Ben-YosefD. Mutated human embryonic stem cells for the study of human genetic disorders // Methods Mol. Biol.-2012.-873.-P. 179-207.

14. Robinton D. A., Daley G. $Q$. The promise of induced pluripotent stem cells in research and therapy // Nature-2012.-481, N 7381.P. 295-305.

15. Gauthier M., Maury Y., Peschanski M., Martinat C. Human pluripotent stem cells for genetic disease modeling and drug screening // Regen. Med.-2011.-6, N 5.-P. 607-622.

16. Meissner A., Wernig M., Jaenisch R. Direct reprogramming of genetically unmodified fibroblasts into pluripotent stem cells // Nat. Biotechnol.-2007.-25, N 10.-P. 1177-1181.

17. Okita K., Ichisaka T., Yamanaka S. Generation of germlinecompetent induced pluripotent stem cells // Nature-2007.-448, N 7151.-P. 313-317.

18. Wernig M., Meissner A., Foreman R., Brambrink T., Ku M., Hochedlinger K., Bernstein B. E., Jaenisch R. In vitro reprogramming of fibroblasts into a pluripotent ES-cell-like state // Nature.2007.-448, N 7151.-P. 318-324.

19. Park I. H., Zhao R., West J. A., Yabuuchi A., Huo H., Ince T. A., Lerou P. H., Lensch M. W., Daley G. Q. Reprogramming of 
human somatic cells to pluripotency with defined factors // Nature.-2008.-451, N 7151.-P. 141-146.

20. Takahashi K., Tanabe K., Ohnuki M., Narita M., Ichisaka T., Tomoda K., Yamanaka S. Induction of pluripotent stem cells from adult human fibroblasts by defined factors // Cell.-2007.131, N 5.-P. 861-872.

21. Yu J., Vodyanik M. A., Smuga-Otto K., Antosiewicz-Bourget J., Frane J. L., Tian S., Nie J., Jonsdottir G. A., Ruotti V., Stewart R., Slukvin I. I., Thomson J. A. Induced pluripotent stem cell lines derived from human somatic cells // Science.-2007.-318, N 5858.-P. 1917-1920.

22. Papapetrou E. P., Lee G., Malani N., Setty M., Riviere I., Tirunagari L. M., Kadota K., Roth S. L., Giardina P., Viale A., Leslie C., Bushman F. D., Studer L., Sadelain M. Genomic safe harbors permit high beta-globin transgene expression in thalassemia induced pluripotent stem cells // Nat. Biotechnol.-2011.-29, N 1.-P. 73-78.

23. Park I. H., Arora N., Huo H., Maherali N., Ahfeldt T., Shimamura A., Lensch M. W., Cowan C., Hochedlinger K., Daley G. Q. Disease-specific induced pluripotent stem cells // Cell.-2008.134, N 5.-P. 877-886.

24. Doyon Y., Vo T. D., Mendel M. C., Greenberg S. G., Wang J., Xia D. F., Miller J. C., Urnov F. D., Gregory P. D., Holmes M. $C$. Enhancing zincfinger nuclease activity with improved obligate heterodimeric architectures // Nat. Methods.-2011.-8, N 1.P. 74-79.

25. Zhang F., Cong L., Lodato S., Kosuri S., Church G. M., Arlotta $P$. Efficient construction of sequence-specific TAL effectors for modulating mammalian transcription // Nat. Biotechnol.-2011.29, N 2.-P. 149-153.

26. Dallerac G., Perronnet C., Chagneau C., Leblanc-Veyrac P., Samson-Desvignes N., Peltekian E., Danos O., Garcia L., Laroche S., Billard J. M., Vaillend C. Rescue of a dystrophin-like protein by exon skipping normalizes synaptic plasticity in the hippocampus of the $m d x$ mouse // Neurobiol. Dis.-2011.-43, N 3.-P. 635-641.

27. Sierant M., Paduszynska A., Kazmierczak-Baranska J., Nacmias B., Sorbi S., Bagnoli S., Sochacka E., Nawrot B. Specific silencing of L392V PSEN1 mutant allele by RNA interference // Int. J. Alzheimers Dis.-2011.-2011.-P. 809281.

28. Wu G., Liu N., Rittelmeyer I., Sharma A. D., Sgodda M., Zaehres H., Bleidissel M., Greber B., Gentile L., Han D. W., Rudolph C., Steinemann D., Schambach A., Ott M., Scholer H. R., Cantz T. Generation of healthy mice from gene-corrected disease-specific induced pluripotent stem cells // PLoS Biol.-2011.-9, N 7.e1001099.

29. Raya I., Rodriguez-Piza I., Navarro S., Richaud-Patin Y., Guenechea G., Sanchez-Danes A., Consiglio A., Bueren J., Izpisua Belmonte J. C. A protocol describing the genetic correction of somatic human cells and subsequent generation of iPS cells // Nat. Prot.-2010.-5, N 4.-P. 647-660.

30. Soldner F., Laganiere J., Cheng A. W., Hockemeyer D., Gao Q., Alagappan R., Khurana V., Golbe L. I., Myers R. H., Lindquist S., Zhang L., Guschin D., Fong L. K., Vu B. J., Meng X., Urnov F. D., Rebar E. J., Gregory P. D., Zhang H. S., Jaenisch R. Generation of isogenic pluripotent stem cells differing exclusively at two early onset parkinson point mutations // Cell.2011.-146, N 2.-P. 318-331.

31. Pawitan J. A. Prospect of induced pluripotent stem cell Genetic repair to cure genetic diseases // Stem Cells Int.-2012.-2012.P. 498197.

32. de Felipe M. M., Feijoo Redondo A. F., Garcia-Sancho J., Schimmang T., Alonso M. B. Cell and gene-therapy approaches to inner ear repair // Histol. Histopathol.-2011.-26, N 7.P. 923-940.

33. Ronaghi M., Nasr M., Heller S. Concise review: inner ear stem cells - an oxymoron, but why? // Stem Cells.-2012.-30, N 1.P. 69-74.

34. Stone J. S., Cotanche D. A. Hair cell regeneration in the avian auditory epithelium // Int. J. Dev. Biol.-2007.-51, N 6-7.P. 633-647.

35. Turner C. W., Reiss L. A., Gantz B. J. Combined acoustic and electric hearing: preserving residual acoustic hearing // Hear Res.2007.-242, N 1-2.-P. 164-171.

36. Martinez-Monedero R., Corrales C. E., Cuajungco M. P., Heller $S$., Edge A. S. Reinnervation of hair cells by auditory neurons after selective removal of spiral ganglion neurons // J. Neurobiol.- 2006.-66, N 4.-P. 319-331.

37. Senn P., Heller S. Stem-cell-based approaches for treating inner ear diseases // HNO.-2008.-56, N 1.-P. 21-26.

38. Devarajan K., Staecker H., Detamore M. S. A review of gene delivery and stem cell based therapies for regenerating inner ear hair cells // J. Funct. Biomater.-2011.-2, N 3.-P. 249-270.

39. Rask-Andersen H., Bostrom M., Gerdin B., Kinnefors A., Nyberg G., Engstrand T., Miller J. M., Lindholm D. Regeneration of human auditory nerve. In vitro/in video demonstration of neural progenitor cells in adult human and guinea pig spiral ganglion // Hear Res.-2005.-203, N 1.-P. 180-191.

40. Oshima K., Grimm C. M., Corrales C. E., Senn P., Martinez-Monedero R., Geleoc G. S., Edge A., Holt J. R., Heller S. Differential distribution of stem cells in the auditory and vestibular organs of the inner ear// J. Assoc. Res. Otolaryngol.-2007.-8, N 1.- P. 18-31.

41. Senn P., Oshima K., Teo D., Grimm C., Heller S. Robust postmortem survival of murine vestibular and cochlear stem cells // J. Assoc. Res. Otolaryngol.-2007.-8, N 2.-P. 194-204.

42. Jeon S. J., Oshima K., Heller S., Edge A. S. Bone marrow mesenchymal stem cells are progenitors in vitro for inner ear hair cells // Mol. Cell. Neurosci.-2007.-34, N 1.-P. 59-68.

43. Coleman B., Fallon J. B., Pettingill L. N., de Silva M. G., Shepherd R. K. Auditory hair cell explant co-cultures promote the differentiation of stem cells into bipolar neurons // Exp. Cell Res.-2007.-313, N 2.-P. 232-243.

44. Hu Z., Wei D., Johansson C. B., Holmstrom N., Duan M., Frisen $J$., Ulfendahl $M$. Survival and neural differentiation of adult neural stem cells transplanted into the mature inner ear // Exp. Cell Res.-2005.-302, N 1.-P. 40-47.

45. Corrales C. E., Pan L., Li H., Liberman M. C., Heller S., Edge A. $S$. Engraftment and differentiation of embryonic stem cell-derived neural progenitor cells in the cochlear nerve trunk: growth of processes into the organ of Corti // J. Neurobiol.-2006.-66, N 13.-P. 1489-1500.

46. Ulfendahl M., Hu Z., Olivius P., Duan M., Wei D. A cell therapy approach to substitute neural elements in the inner ear// Physiol. Behav.-2007.-92, N 1-2.-P. 75-79.

47. Nakagawa T., Ito J. Cell therapy for inner ear diseases // Curr. Pharm. Des.-2005.-11, N 9.-P. 1203-1207.

48. Oshima K., Suchert S., Blevins N. H., Heller S. Curing hearing loss: patient expectations, health care practitioners, and basic science // J. Commun. Disord.-2010.-43, N 4.-P. 311-318.

49. Oshima K., Shin K., Diensthuber M., Peng W. A., Ricci J. A., Heller $S$. Mechanosensitive Hair Cell-like cells from embryonic and induced pluripotent stem cells // Cell.-2010.-141, N 4.P. 704-716.

50. Martinez-Monedero R., Edge A. S. Stem cells for the replacement of inner ear neurons and hair cells // Int. J. Dev. Biol.-2007.-51, N 6-7.-P. 655-661. 
51. Boyer L. A., Lee T. I., Cole M. F., Johnstone S. E., Levine S. S. Zucker J. P., Guenther M. G., Kumar R. M., Murray H. L., Jenner R. G., Gifford D. K., Melton D. A., Jaenisch R., Young R. A. Core transcriptional regulatory circuitry in human embryonic stem cells //Cell.-2005.-122, N 6.-P. 947-956.

52. Grinnemo K. H., Sylven C., Hovatta O., Dellgren G., Corbascio $M$. Immunogenicity of human embryonic stem cells // Cell Tissue Res.-2008.-331, N 1.-P. 67-78.

53. Sekiya T., Kojima K., Matsumoto M., Kim T. S., Tamura T., Ito $J$. Cell transplantation to the auditory nerve and cochlear duct // Exp. Neurol.-2006.-198, N 1.-P. 12-24.

54. Jongkamonwiwat N., Zine A., Rivolta M. N. Stem cell based therapy in the inner ear: appropriate donor cell types and routes for transplantation // Curr. Drug Targets.-2010.-11, N 7.-P. 888897.

55. Kamiya K., Fujinami Y., Hoya N., Okamoto Y., Kouike H., Komatsuzaki R., Kusano R., Nakagawa S., Satoh H., Fujii M., Matsunaga $T$. Mesenchymal stem cell transplantation accelerates hearing recovery through the repair of injured cochlear fibrocytes // Am. J. Pathol.-2007.-171, N 1.-P. 214-226.

56. Matsuoka A. J., Kondo T., Miyamoto R. T., Hashino E. In vivo and in vitro characterization of bone marrow derived stem cells in the cochlea // Laryngoscope.-2006.-116, N 8.-P. 1363-1367.

57. Vlastarakos P. V., Nikolopoulos T. P., Tavoulari E., Papacharalambous $G$., Tzagaroulakis A., Dazert $S$. Sensory cell regeneration and stem cells: what we have already achieved in the management of deafness // Otol. Neurotol.-2008.-29, N 6.-P. 758-768.

58. Beites C. L., Kawauchi S., Crocker C. E., Calof A. L. Identification and molecular regulation of neural stem cells in the olfactory epithelium // Exp. Cell Res.-2005.-306, N 2.-P. 309-316.

59. Low C. B., Liou Y. C., Tang B. L. Neural differentiation and potential use of stem cells from the human umbilical cord for central nervous system transplantation therapy // J. Neurosci. Res.2008.-86, N 8.-P. 1670-1679.

60. Lang H., Ebihara Y., Schmiedt R. A., Minamiguchi H., Zhou D., Smythe N., Liu L., Ogawa M., Schulte B. A. Contribution of bone marrow hematopoietic stem cells to adult mouse inner ear: mesenchymal cells and fibrocytes // J. Comp. Neurol.-2006.496, N 2.-P. 187-201.

61. Doyle K. L., Kazda A., Hort Y., McKay S. M., Oleskevich S. Differentiation of adult mouse olfactory precursor cells into hair cells in vitro // Stem Cells.-2007.-25, N 3.-P. 621-627.

62. Sharif S., Nakagawa T., Ohno T., Matsumoto M., Kita T., Riazud$\operatorname{din} S$., Ito $J$. The potential use of bone marrow stromal cells for cochlear cell therapy // Neuroreport.-2007.-18, N 4.-P. 351-354.

63. Jaenisch R., Young R. Stem cells, the molecular circuitry of pluripotency and nuclear reprogramming // Cell.-2008.-132, N 4.P. 567-582.

64. Kim J. B., Greber B., Arauzo-Bravo M. J., Meyer J., Park K. I., Zaehres H., Scholer H. R. Direct reprogramming of human neural stem cells by OCT4 // Nature-2009.-461, N 7264.-P. 649653.

65. Nishimura K., Nakagawa T., Ono K., Ogita H., Sakamoto T., Yamamoto N., Okita K., Yamanaka S., Ito J. Transplantation of mouse induced pluripotent stem cells into the cochlea // Neuroreport.-2009.-20, N 14.-P. 1250-1254.

66. Lanza R. Stem cell breakthrough: don't forget ethics // Science.2007.-318, N 5858.-P. 1865

67. Jin Z. B., Okamoto S., Mandai M., Takahashi M. Induced pluripotent stem cells for retinal degenerative diseases: a new perspective on the challenges // J. Genet.-2009.-88, N 4.-P. 417-424.

68. Jindal N., Mukhopadhyay A., Anand A. The emerging role of stem cells in ocular neurodegeneration: hype or hope? // Mol. Cell Biochem.-2012.-365, N 1-2.-P. 65-76.
69. Pradhan M., Hayes I., Vincent A. An audit of genetic testing in diagnosis of inherited retinal disorders: a prerequisite for genespecific intervention // Clin. Experiment. Ophthalmol.-2009.37, N 7.-P. 703-711

70. Crigler L., Robey R. C., Asawachaicharn A., Gaupp D., Phinney $D$. $G$. Human mesenchymal stem cell subpopulations express a variety of neuro regulatory molecules and promote neuronal cell survival and neurogenesis // Exp. Neurol.-2006.-198, N 1.P. 54-64.

71. Pluchino S., Zanotti L., Rossi B., Brambilla E., Ottoboni L., Salani G., Martinello M., Cattalini A., Bergami A., Furlan R., Comi $G$., Constantin G., Martino $G$. Neurosphere-derived multipotent precursors promote neuroprotection by an immunomodulatory mechanism // Nature.-2005.-436, N 7048.-P. 266-271.

72. Lee H. J., Lim I. J., Lee M. C., Kim S. U. Human neural stem cells genetically modified to overexpress brain-derived neurotrophic factor promote functional recovery and neuroprotection in a mouse stroke model // J. Neurosci. Res.-2010.-88, N 15.-P. 3282-3294.

73. Bull N. D., Martin K. R. Concise review: toward stem cell-based therapies for retinal // Stem Cells.-2011.-29, N 8.-P. 11701175.

74. Stern J. H., Temple S. Stem cells for retinal replacement therapy // Neurotherapeutics.-2011.-8, N 4.-P. 736-743.

75. Djojosubroto $M$. W., Arsenijevic $Y$. Retinal stem cells: promising candidates for retina transplantation //Cell Tissue Res.2008.-331, N 1.-P. 347-357.

76. Wong I. Y., Poon M. W., Pang R. T., Lian Q., Wong D. Promises of stem cell therapy for retinal degenerative diseases // Graefes Arch. Clin. Exp. Ophthalmol.-2011.-249, N 10.-P. 1439-1448.

77. Osakada F., Ikeda H., Sasai Y., Takahashi M. Stepwise differentiation of pluripotent stem cells into retinal cells // Nat. Protoc.2009.-4, N 6.-P. 811-824.

78. Osakada F., Jin Z. B., Hirami Y., Ikeda H., Danjyo T., Watanabe $K$., Sasai Y., Takahashi M. In vitro differentiation of retinal cells from human pluripotent stem cells by small-molecule induction // J. Cell Sci.-2009.-122, Pt 17.-P. 3169-3179.

79. Buchholz D. E., Hikita S. T., Rowland T. J., Friedrich A. M., Hinman C. R., Johnson L. V., Clegg D. O. Derivation of functional retinal pigmented epithelium from induced pluripotent stem cells // Stem Cells.-2009.-27, N 10.-P. 2427-2434.

80. Idelson M., Alper R., Obolensky A., Ben-Shushan E., Hemo I., Yachimovich-Cohen N., Khaner H., Smith Y., Wiser O., Gropp M., Cohen M. A., Even-Ram S., Berman-Zaken Y., Matzrafi L., Rechavi G., Banin E., Reubinoff B. Directed differentiation of human embryonic stem cells into functional retinal pigment epithelium cells // Stem Cells.-2009.-5, N 4.-P. 396-408.

81. Aoki H., Hara A., Niwa M., Motohashi T., Suzuki T., Kunisada $T$. Transplantation of cells from eye-like structures differentiated from embryonic stem cells in vitro and in vivo regeneration of retinal ganglion-like cells // Graefes Arch. Clin. Exp. Ophthalmol.-2008.-246, N 2.-P. 255-265.

82. Vaajasaari H., Ilmarinen T., Juuti-Uusitalo K., Rajala K., Onnela N., Narkilahti S., Suuronen R., Hyttinen J., Uusitalo H., Skottman H. Toward the defined and xeno-free differentiation of functional human pluripotent stem cell-derived retinal pigment epithelial cells // Mol. Vis.-2011.-17.-P. 558-575.

83. Eiraku M., Takata N., Ishibashi H., Kawada M., Sakakura E., Okuda S., Sekiguchi K., Adachi T., Sasai Y. Self-organizing opticcup morphogenesis in three dimensional culture // Nature.-2011.472, N 7341.-P. 51-56.

84. Aftab U., Jiang C., Tucker B., Kim J. Y., Klassen H., Miljan E., Sinden J., Young $M$. Growth kinetics and transplantation of human retinal progenitor cells // Exp. Eye Res.-2009.-89, N 3.P. 301-310. 
85. Lamba D. A., Gust J., Reh T. A. Transplantation of human embryonic stem cell-derived photoreceptors restores some visual function in Crx-deficient mice // Stem Cells.-2009.-4, N 1.P. 73-79.

86. Park U. C., Cho M. S., ParkJ. H., Kim S. J., Ku S. Y., Choi Y. M., Moon $S$. Y., Yu H. G. Subretinal transplantation of putative retinal pigment epithelial cells derived from human embryonic stem cells in rat retinal degeneration model // Clin. Exp. Reprod. Med.-2011.-38, N 4.-P. 216-221.

87. Inoue T., Coles B. L., Dorval K., Bremner R., Bessho Y., Kageyama R., Hino S., Matsuoka M., Craft C. M., McInnes R. R., Tremblay F., Prusky G. T., Kooy D. Maximizing functional photoreceptor differentiation from adult human retinal stem cells // Stem Cells.-2010.-28, N 3.-P. 489-500.

88. MacLaren R. E., Pearson R. A., MacNeil A., Douglas R. H., Salt T. E., Akimoto M., Swaroop A., Sowden J. C., Ali R. R. Retinal repair by transplantation of photoreceptor precursors // Nature.2006.-444, N 7116.-P. 203-207.

89. Lawrence J. M., Singhal S., Bhatia B., Keegan D. J., Reh T. A., Luthert P. J., Khaw P. T. Limb G. A. MIO-M1 cells and similar muller glial cell lines derived from adult human retina exhibit neural stem cell characteristics // Stem Cells.-2007.-25, N 8.P. 2033-2043.

90. MacNeil A., Pearson R. A., MacLaren R. E., Smith A. J., Sowden J. C., Ali R. R. Comparative analysis of progenitor cells isolated from the iris, pars plana, and ciliary body of the adult porcine eye // Stem Cells.-2007.-25, N 10.-P. 2430-2438.

91. Gualdoni S., Baron M., Lakowski J., Decembrini S., Smith A. J., Pearson R. A., Ali R. R., Sowden J. C. Adult ciliary epithelial cells, previously identified as retinal stem cells with potential for retinal repair, fail to differentiate into new rod photoreceptors // Stem Cells.-2010.-28, N 6.-P. 1048-1059.

92. Harris J. R., Fisher R., Jorgensen M., Kaushal S., Scott E. W. CD133 progenitor cells from the bone marrow contribute to retinal pigment epithelium repair // Stem Cells.-2009.-27, N 2.P. 457-466.

93. Zwart I., Hill A. J., Al-Allaf F., Shah M., Girdlestone J., Sanusi A. B., Mehmet H., Navarrete R., Navarrete C., Jen L.S. Umbilical cord blood mesenchymal stromal cells are neuroprotective and promote regeneration in a rat optic tract model // Exp. Neurol.-2009.-216, N 2.-P. 439-448.
94. Tian B., Li X. X., Shen L., Zhao M., Yu W. Z. Auto-mobilized adult hematopoietic stem cells advance neovasculature in diabetic retinopathy of mice // Chin. Med. J. (Engl.)-2010.-123, N 16.P. 2265-2268.

95. Lian Q., Zhang Y., Zhang J., Zhang H. K., Wu X., Zhang Y., Lam F. F., Kang S., Xia J. C., Lai W. H., Au K. W., Chow Y. Y., Siu C. W., Lee C. N., Tse H. F. Functional mesenchymal stem cells derived from human induced pluripotent stem cells attenuate limb ischemia in mice // Circulation.-2010.-121, N 9.-P. 1113-1123.

96. Levkovitch-Verbin H., Sadan O., Vander S., Rosner M., Barhum $Y$., Melamed E., Offen D., Melamed S. Intravitreal injections of neurotrophic factors secreting mesenchymal stem cells are neuroprotective in rat eyes following optic nerve transection // Invest. Ophthalmol. Vis. Sci.-2010.-51, N 12.-P. 6394-6400.

97. Xu H., Sta Iglesia D. D., Kielczewski J. L., Valenta D. F., Pease M. E., Zack D. J., Quigley H. A. Characteristics of progenitor cells derived from adult ciliary body in mouse, rat, and human eyes // Invest. Ophthalmol. Vis. Sci.-2007.-48, N 4.-P. 1674-1682.

98. Djojosubroto M., Bollotte F., Wirapati P., Radtke F., Stamenkovic I., Arsenijevic Y. Chromosomal number aberrations and transformation in adult mouse retinal stem cells in vitro // Invest. Ophthalmol. Vis. Sci.-2009.-50, N 12.-P. 5975-5987.

99. Zhou L., Wang W., Liu Y., Fernandez de Castro J., Ezashi T., Telugu B. P., Roberts R. M., Kaplan H. J., Dean D. C. Differentiation of induced pluripotent stem cells of swine into rod photoreceptors and their integration into the retina // Stem Cells.2011.-29, N 6.-P. 972-980.

100. Hara A., Aoki H., Takamatsu M., Hatano Y., Tomita H., Kuno T., Niwa M., Kunisada T. Human embryonic stem cells transplanted into mouse retina induces neural differentiation // Stem Cells and Cancer Stem Cells.-2012.-2, N 4.-P. 291-298.

101. Meyer J. S., Howden S. E., Wallace K. A., Verhoeven A. D., Wright L. S., Capowski E. E., Pinilla I., Martin J. M., Tian S., Stewart R., Pattnaik B., Thomson J. A., Gamm D. M. Optic vesicle-like structures derived from human pluripotent stem cells facilitate a customized approach to retinal disease treatment // Stem Cells.2011.-29, N 8.-P. 1206-1218. 